
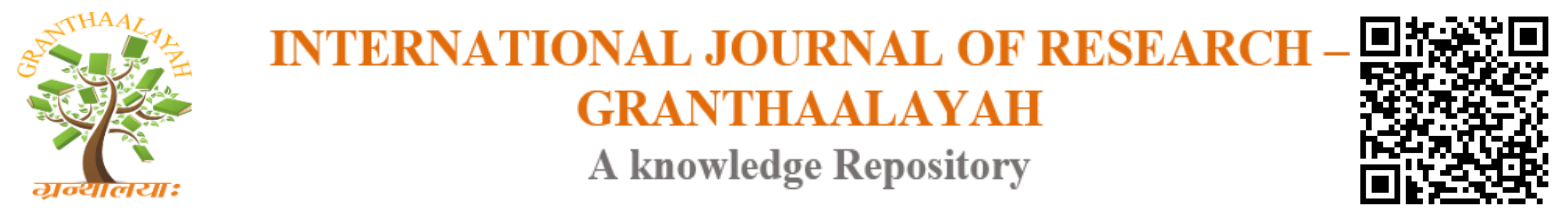

Social

\title{
INDOOR COMFORT CONDITIONS IN TERMS OF USER SATISFACTION FOR MIDDLE-INCOME GROUPS: THE CASE OF ATAEVLER, BURSA, TURKEY
}

\author{
Miray Gür ${ }^{1}$, Filiz Şenkal Sezer ${ }^{2}$ \\ ${ }^{1,2}$ Uludag University, Faculty of Architecture, Department of Architecture, Turkey
}

\begin{abstract}
The objective of this research paper is to investigate residents' perception of indoor comfort conditions and user satisfaction in the residences for middle-income groups, focusing on thermal, visual and acoustical comfort. For this purpose, a residential satisfaction survey was conducted to residents of 5 housing estates in Ataevler, Bursa, Turkey. The study consists of literature review, evaluation of user satisfaction survey, and discussion of the research findings focusing on improving indoor environment. The questionnaires were applied to residents and they were asked to express their perception of indoor comfort and their satisfaction level with comfort parameters in which they live in. The answers have statically been analyzed in terms of percentages through SPSS 13.0. The results obtained indicate that the main dissatisfaction factors related to comfort conditions of middle income groups in their housing estates were related to indoor-outdoor noise problems and inadequate daylight received. The results suggest that comfort levels of users related to climatic factors vary based on their house and seasons. Heating levels of buildings are adjusted based on the comfort of the users. Comfort levels related to indoor-outdoor noise are very low. Satisfaction levels from visual comfort is low in buildings that were constructed close to each other because of inadequate daylight. Achieving optimal visual, acoustical, and climatic comfort conditions is essential to create a positive impact on users' performance in houses. The results of this study and suggested comfort conditions are expected to contribute to building policies, building producers, academia and to the implementation of high quality, healthy and energy efficient houses.
\end{abstract}

Keywords: User Comfort; Indoor Comfort Conditions; Bursa; User Satisfaction; Middle-Income Housing; Daylight.

Cite This Article: Miray GÜR, and Filiz ŞENKAL SEZER. (2018). "INDOOR COMFORT CONDITIONS IN TERMS OF USER SATISFACTION FOR MIDDLE-INCOME GROUPS: THE CASE OF ATAEVLER, BURSA, TURKEY." International Journal of Research Granthaalayah, 6(6), 522-535. https://doi.org/10.29121/granthaalayah.v6.i6.2018.1398. 


\section{Introduction}

User comfort and indoor air quality are certain issues associated with human health and well-being of society as a total sense of physical, mental and social well-being. World Health Organization reported that maintaining optimum indoor climate in buildings is important for occupants in terms of human health, comfort and productivity [1]. As a result, the users' performance and satisfaction are influenced by the comfort conditions of indoor environment. In this context, five selected case building were evaluated based on the perceptions of comfort in the physical environment, by considering the determinants of indoor comfort conditions including climatic, visual, acoustical aspects. Prior to the field study, a research was conducted on the architectural features of case buildings, together with a literature review on previous studies on healthy housing, visual-thermalacoustic comfort, impact of comfort conditions on user satisfaction with indoor spaces, health and healthy buildings.

The concept of healthy buildings or healthy housing improves the quality of life of users due to production of adequate and safe houses. In this regard it is a necessity to produce healthy houses that will respect various policies [2]. The quality of indoor air, climate comfort and noise are important for a healthy environment and should be provided to avoid various health risks. These risks are mentioned in the discussion section of this article. Guidelines that address factors affecting health in terms of climatic, visual, acoustical aspects that are applicable to both new and existing housing stock are valuable for local public health agencies that seek to upgrade local housing codes [3]. Thermal, acoustic and visual comfort conditions are all influencial to indoor environmental quality. In different studies, climatic comfort, which is followed by acoustic and visual comfort, are regarded as the preconditions of high indoor environment quality and healthy housing. Satisfaction with climatic confort has a positive effect on the overall satisfaction with indoor environment [4]. World Health Organization has developed a guideline on the appropriate indoor temperature, especially for residences [5]. This shows the important impact of climatic comfort on health, since WHO aims to protect the health of residents. In various studies in addition to the satisfaction from climatic conditions, acoustic comfort comes as a secondary factor with significant impact on satisfaction from indoor spaces and health [4,6,7]. On the other hand, artificial lighting is not as significant as other factors or does not directly affect satisfaction from indoor spaces [4].

Climatic, visual and acoustical comfort conditions have a significant impact on user satisfaction in dwellings and are related to the physical condition of housing, typologies, locations in the city center, duration of use, income groups they are targeting, or tenure status $[8,9,10,11]$. When studies on the perception of comfort is evaluated, it is seen that a study on comfort conditions of residents in a Danish housing estate examined visual, acoustic, thermal and air quality aspects and the effects of residential features on comfort together with the expectations of users. In this context, the topics that were investigated were: parameters that provided a good indoor climate, the satisfaction level of users from the indoor comfort parameters, features that provided comfort to the respondents, climatic comfort level of residents, and the behavior and preferences of residents related to indoor climate comfort control. In the study, it was found that the conditions of the housing environment (such as the position of the house, daylight) were important for providing comfort in the interior and that the indoor thermal, visual, acoustic or air quality parameters increased indoor comfort [12]. The comfort conditions vary based on residential areas or income groups where the research is conducted. In a study conducted in Nigeria, thermal and visual 
comfort are regarded as the most effective design and construction parameters on user satisfaction in housing, and satisfaction with climate and daylight has a positive impact on satisfaction with dwellings $[9,10]$.

In the literature, in addition to studies where all comfort conditions are considered, there are studies and surveys that focus on certain comfort conditions such as climate or lighting. It is clear in the literature that thermal comfort is important for the individual to adapt to the dwelling and its surroundings. Thermal comfort conditions vary according to the time of the day as well as the layout of building blocks [13]. In a survey conducted during summer in Australia on thermal comfort, which is a very important factor for health an indoor space satisfaction, users were assessed for their level of satisfaction with their thermal comfort and their behavior in controlling indoor climate. The data in the study showed that residents' responses to questions such as outdoor temperature and the amount of airflow related to ambient temperature inside and outside of their buildings were varied. In addition, it was found that some of the qualities that are included in the design of building blocks and interior spaces such as operable windows, ceiling fans, etc. were essential to thermal comfort. Similar results were obtained in a study conducted in public housing in Singapore, where air movement in the house was found to be influential in user satisfaction with thermal comfort [13]. However, in studies conducted in different countries, it has been observed that behavior such as opening windows and ventilating fan use was often preferred by users for climate control of the indoor environment, which is associated with air movement $[13,14,15]$. This shows that the location of the building blocks, their relationship to each other, and their location, has an impact on airflow, which in turn affects thermal comfort. In addition to the organization of the buildings, orientation of houses should be carefully planned in the design, taking into consideration the variation of the temperature in the indoor environment due to sunlight at different times of the day. To adjust indoor temperature or ventilation based on user requirements, it is important to integrate the structural elements and systems to the facades and structural spaces, such as windows, ventilator fans or sun breakers (to reduce the temperature during summer).

Depending on the organization of the buildings or the layout of the house, factors such as thermal comfort, light levels, visual and luminous comfort and the necessity of artificial lighting during daytime are formed. A study on the effects of daylight on visual and luminous comfort in residential units in Hong Kong has shown that daylight satisfaction level is increased in residences located on higher floors and in buildings with large window openings. On the other hand, in houses facing south, the satisfaction of daylight level is higher than other directions. The study also reached a conclusion indicating that level of satisfaction with daylight was very important on luminous comfort and general housing satisfaction; that satisfaction with daylight changed in summer and winter months due to the change in the daylight levels, and external obstruction in high and dense building sites negatively affects daylight satisfaction [16]. Another study in Hong Kong, where dense residential zones were examined, indicates that the distance between buildings have an impact on the comfort of users from daylight levels [17]. In this framework, the level of satisfaction from daylight can be expected to decrease in apartments with high and dense building blocks. Position of building blocks from each other, layout of sites, residential equipment for residents' air and daylight control, size of the facade gaps, and height of apartments affecting airflow and daylight level, and changing level of comfort in summer and winter months are important parameters affecting the comfort of users and should be considered in building design. 
In order to ensure satisfaction from residences, which is related to the comfort level of residents, it will be beneficial to consider such qualities for the settlement of the housing area and for the design of the interior spaces of residences. In this framework, this study, aims to determine, comfort conditions in houses based on resident opinions, the affect of comfort conditions on housing satisfaction and the parameters that should be taken into consideration in architectural design for increasing both satisfaction with comfort conditions and houses.

It is indicated that for producing healthy residences the surveys conducted by WHO (2007) on residence users should be taken into considerations [18]. In this context, the user perception and satisfaction with the indoor environment conditions can be examined from the responses of the user surveys. The research aims to cover heating, air-conditioning, ventilation, natural and artificial lighting, indoor air quality, acoustical and visual issues depending on the user opinions and residential satisfaction based on comfort conditions. A POE (post-occupancy evaluation) study is carried out within the scope of a research on developing optimum use of the climatic, auditory and visual comfort conditions in residences for the middle-income groups and to suggest proposals to increase housing satisfaction.

From this point of view, a field study was conducted to determine user expectations about comfortable indoor conditions in housing apartments and to what extent these expectations are met. Orta gelir grubu kullanıcılarının konut edinimine yönelik süreçte, öncelik konut sahibi olmalarına, iç mekan konfor koşullarının ikinci planda tutulması birbirine çok yakın blokların oluşmasına ve, yalıtımsız uygulamalar yapılmasına neden olmuştur. Konut üretiminin ve edinimi sürecinin sağlıklı bir şekilde yürütülmesine yönelik olarak çalışma, kullanıcıların konfor ve iç mekankoşullarından memnuniyetinin artırılması ve enerji vermliliğin sağlanması açısından konut tasarımına yönelik öneriler geliştirilmesi perspektifinden önem taşımaktadır.

\section{Materials and Methods}

In the scope of conducting the POE, Ataevler district in the city of Bursa was selected for the field study and with the goal of reaching at least $35 \%$ of the total dwellers in 5 different housing estates in April 2018; accordingly a total of 150 housing users were interviewed (23 from Sample 1, 33 from Sample 2, 30 from Sample 3, 41 from Sample 4, and 23 from Sample 5). The user satisfaction survey is developed based on 5 point Likert scale ranging from very satisfied to very unsatisfied. The questionnaire involves 4 questions regarding the key themes such as: thermal, acoustical and visual comfort sensation. Interviews were held with users of houses for middle income groups in Ataevler in category via this voluntary questionnaire. The answers have statically been analyzed in terms of percentages. The attained results are illustrated in graphs in the research findings section. The results were evaluated in SPSS v13.0 [19].

Bursa is the 4th most populated metropolitan city with a population of 2,5 million in Turkey. It is located between the south-east cost of the Marmara Sea and the north western slopes of Uludag Mountain. Temperate climate of the region is characterized with warm summers and mild winters. In Figure 1, studied residential locations within Ataevler districts are marked on Google Maps. Ataevler is a developed and still developing district of Bursa with intensive housing and traffic flow. The residential buildings consist of mostly of high-rise building estates for middle income groups, where building height is maximum of 5-6 storeys. In the study residence satisfaction was 
evaluated from the viewpoint of comfort conditions and all of the selected houses for the study had three bedrooms and one living room and were heated with natural gas systems. The selected buildings are naturally ventilated and illuminated through window openings. Daylight is supported by pendant light windows. For climate control, some of the homes are equipped with AC system.

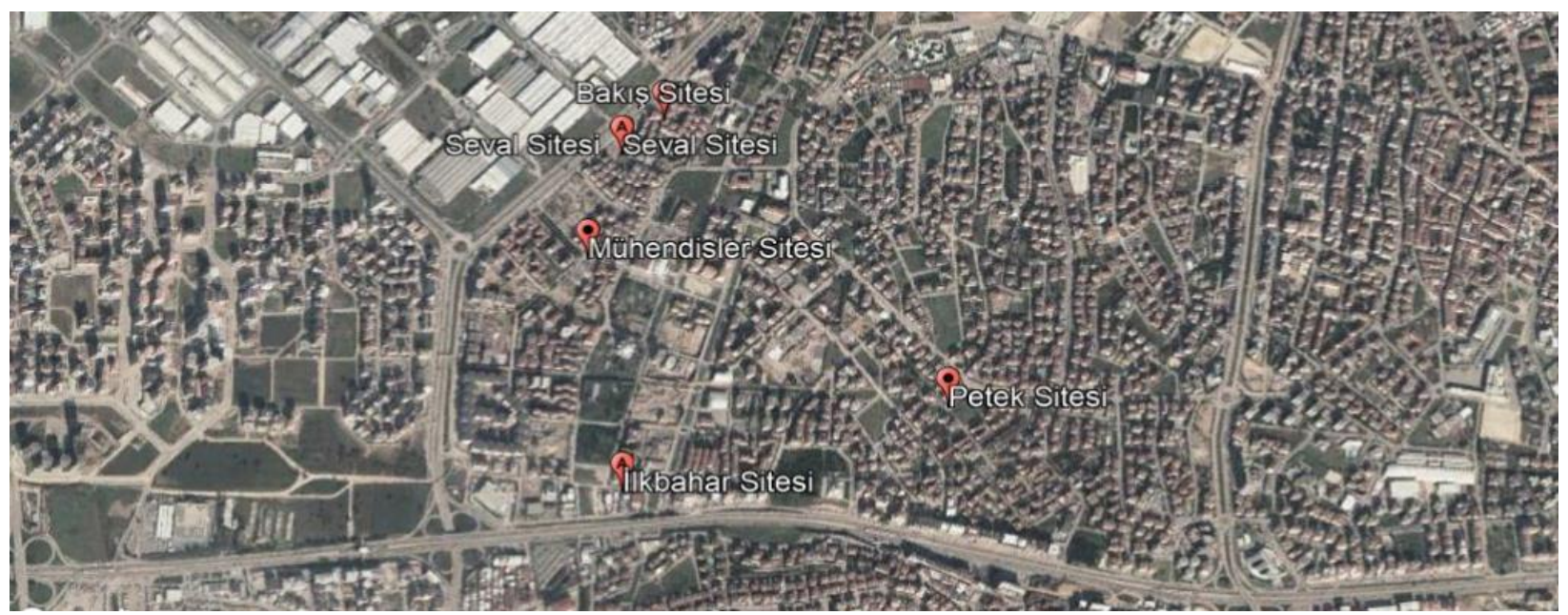

Figure 1: Location of the case buildings: Site Petek: Sample 1, Site Bakis: Sample 2, Site Seval: Sample 3, Site Muhendisler: Sample 4, Site İlkbahar: Sample 5 [20].

Sample 1 (Petek Sitesi): Example A (Egemen Evler): Built in 1992 with a reinforced concrete system, Sample 1 consists of 4 blocks each with 5 storeys; 2 of the blocs have 3 apartments and the other 2 blocks have 2 apartments on each floor. All the housing estate consists of $3+1$ houses of 150 square meters. Shops are located on the ground floor of the blocks (Figure 2).
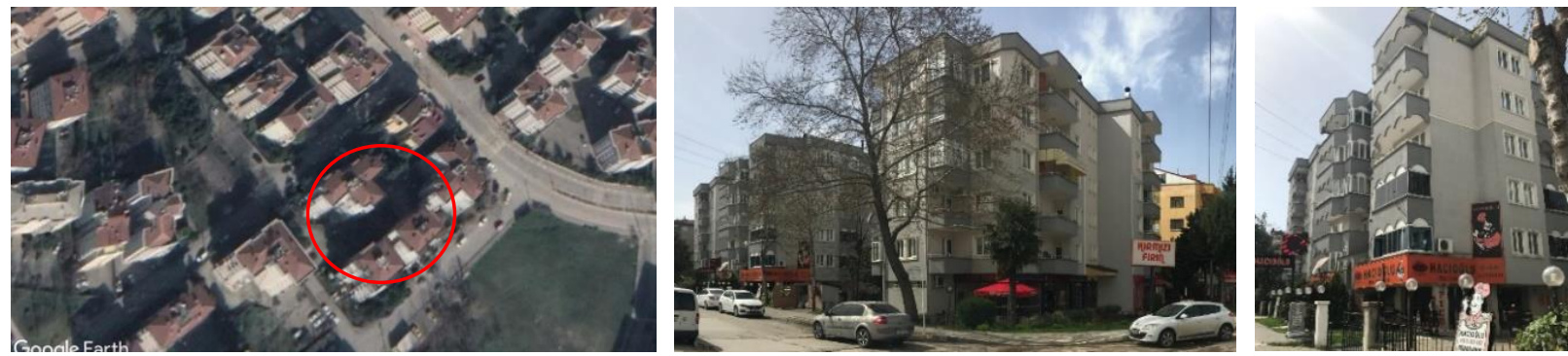

Figure 2: Photographs taken from the Sample 1

Sample 2 (Bakış Sitesi): Built in 1994 with a reinforced concrete system, Sample 2 consists of 9 blocks with 5 storeys each; there are 2 apartments on each floor. All the housing estate consists of $3+1$ houses of about 130 square meters (Figure 3 ).
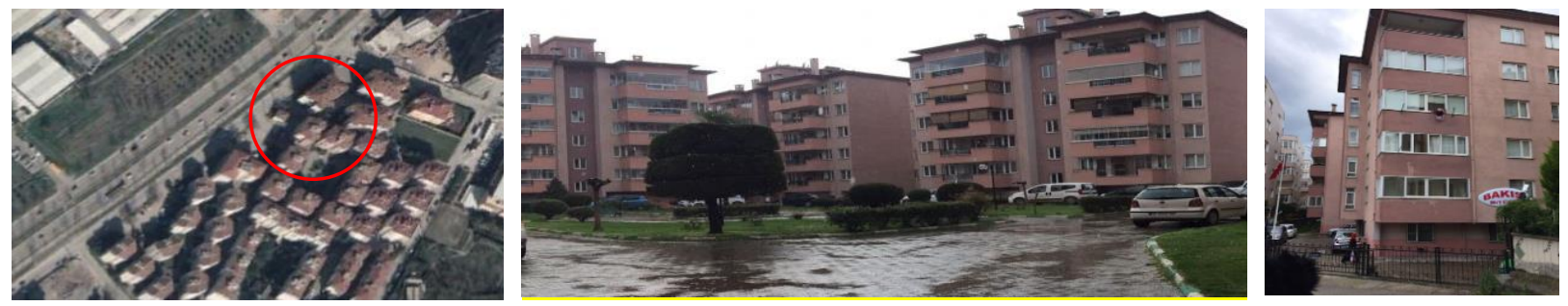

Figure 3: Photographs taken from the Sample 2 
Sample 3 (Seval Sitesi): Built in 1997 with a reinforced concrete system, Sample 3 consists of 11 blocks with 4 storeys each; there are 2 apartments on each floor. All the housing estate consists of $3+1$ houses of 110 square meters (Figure 4 ).
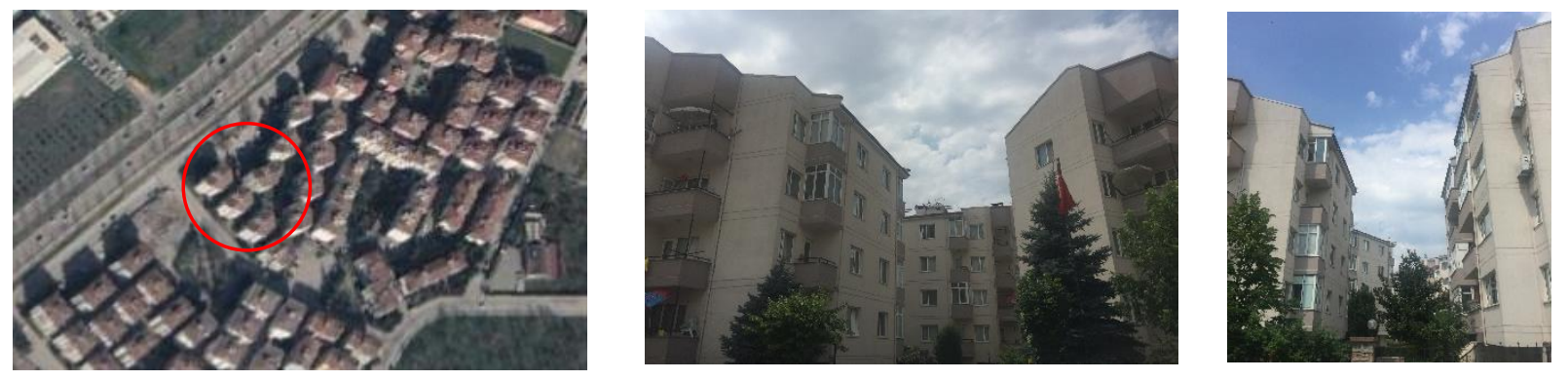

Figure 4: Photographs taken from the Sample 3

Sample 4 (Mühendisler Sitesi): Built in 1995 with a reinforced concrete system, Sample 4 consists of 8 blocks with 5 storeys each; there are 2 apartments on each floor. All the housing estate consists of $3+1$ houses of 120 square meters (Figure 5).
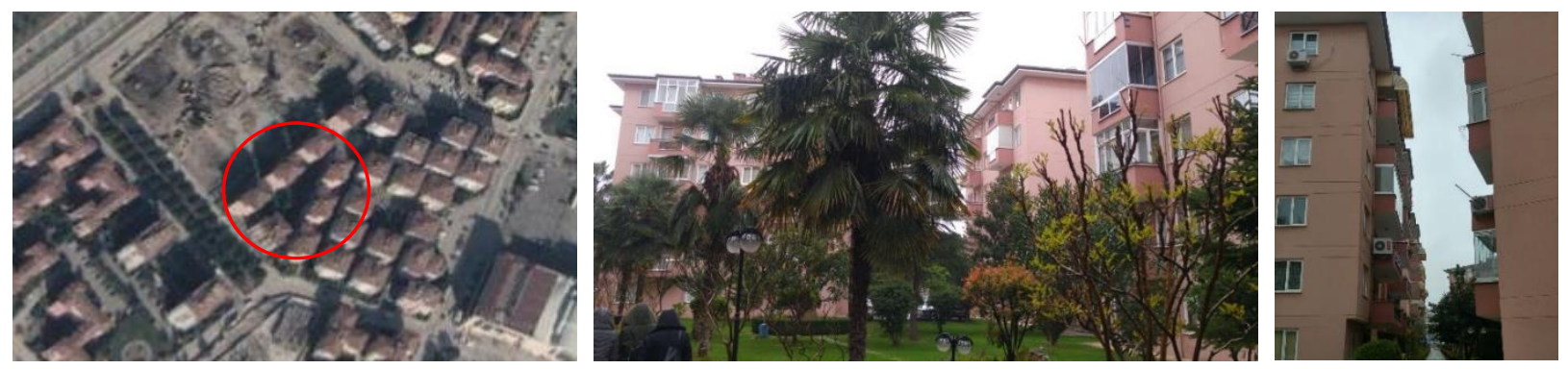

Figure 5: Photographs taken from the Sample 4

Sample 5 (İlkbahar Sitesi): Built in 2003 with a reinforced concrete system, Sample 5 consists of 2 blocks with 6 storeys each; there are 2 apartments on each floor. All of the housing estate consists of $3+1$ houses of 120 square meters (Figure 6).
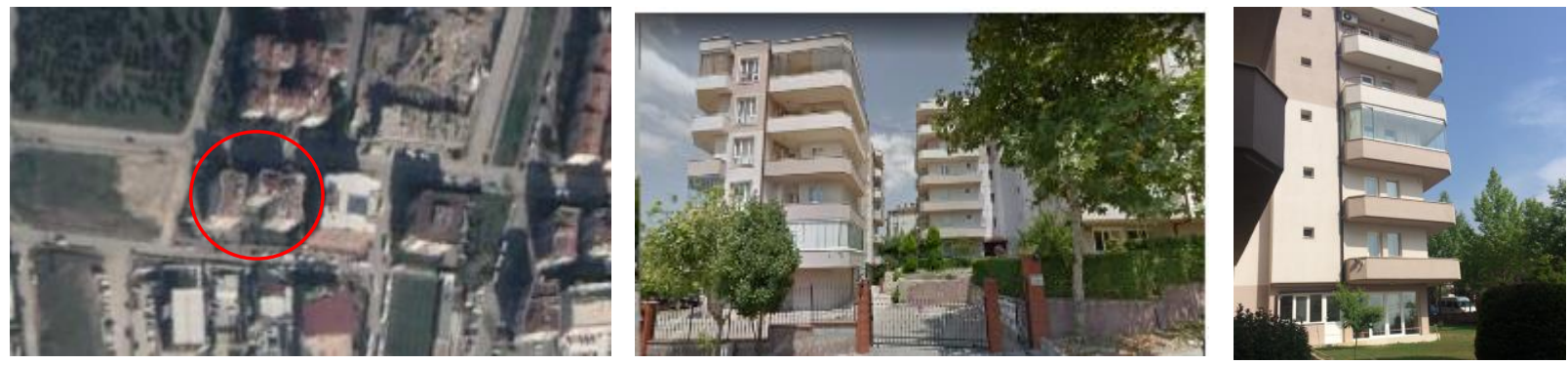

Figure 6: Photographs taken from the Sample 5

\section{Results and Discussion}

In the first section four questions were asked, mainly consisting of the respondent's sociodemographic information. General information regarding demographic information for the residents of all gated communities is given below (Table 1). 
The general information of gender, age, educational status and jobs of respondents acquired by the survey in all cases are given respectively. Out of total participants, 60\% of respondents were female and $40 \%$ were male which shows that the majority of the respondents were female. Survey results show that, $14 \%$ were between 19-25 years old, $24 \%$ were between 26-35 years old, $22 \%$ were between $36-45$ years old, $25 \%$ were between $46-55$ years old, and $15 \%$ of the respondents were above the age of $55.2 \%$ of respondents reported to have master degrees, $39 \%$ have bachelor's degrees; $39 \%$ have high school education and $20 \%$ have only secondary school education.

Table 1: Demographic characteristics

\begin{tabular}{|l|l|l|l|l|l|}
\hline Gender: & Sample 1 & Sample 2 & Sample 3 & Sample 4 & Sample 5 \\
\hline Female & 61,9 & 48 & 59 & 51,8 & 78,3 \\
\hline Male & 38,1 & 52 & 41 & 48,2 & 21,7 \\
\hline Age: & & & & & \\
\hline Under 18 years old & 9,5 & 24 & 9 & 8,4 & 17,4 \\
\hline 18-25 years old & 33,3 & 24 & 23 & 20,8 & 21,7 \\
\hline 26-35 years old & 19 & 28 & 27 & 20,8 & 13 \\
\hline 36-45 years old & 38,2 & 12 & 27 & 25 & 21,7 \\
\hline 46-55 years old & 0 & 12 & 14 & 25 & 26,2 \\
\hline 55 years or older & 9,5 & 24 & 9 & 8,4 & 17,4 \\
\hline Educational status: & & & & & \\
\hline Secondary school graduate & 23,8 & 25 & 16 & 8,4 & 26,1 \\
\hline High school graduate & 39,1 & 29,6 & 48 & 32,3 & 47,8 \\
\hline Bachelor's degree & 37,1 & 45,4 & 36 & 51 & 26,1 \\
\hline Postgraduate & 0 & 0 & 0 & 8,3 & 0 \\
\hline Occupation: & & & & & \\
\hline Employed & 61,9 & 56 & 60 & 45,8 & 30,4 \\
\hline Student & 4,8 & 12 & 5 & 8,3 & 13 \\
\hline Housewife & 33,3 & 12 & 15 & 16,7 & 39,1 \\
\hline Retired & 0 & 20 & 20 & 29,2 & 17,5 \\
\hline
\end{tabular}

The results reveal that there was diversity in terms of education among the residents who participated in the questionnaire. Regarding occupational distribution of the residents, $51 \%$ were employed, $9 \%$ were students, $23 \%$ were housewives and $17 \%$ were retired. In Ataevler, $2 \%$ of the apartments had one resident, whereas $19 \%$ had two, 35\% had three, $\% 39$ had four and 5\% had five or more residents. Regarding ownership status of the properties, $65 \%$ of the residents were homeowners, $30 \%$ were tenants, and $5 \%$ were living with relatives.

In the study, a total of 6 questions were asked under these main topics: thermal environment, acoustic issues and lighting. In this section, perception of physical comfort in houses are evaluated. The users were asked to evaluate the negative and positive aspects of houses and give a rating about existing comfort conditions. The answers illustrated in graphs reflect the impact of the current comfort level particularly for indoors, which affects the user's performance and well-being. Six comfort issues were presented in graphs using a 5-point Likert scale with responses from 1strongly disagree to 5 - strongly agree. 
According to American Society of Heating, Refrigeration and Air Conditioning Engineers (ASHRAE) Standard 55, thermal comfort is defined as "The state of mind which expresses satisfaction with the thermal environment". Thermal environmental conditions are defined as acceptable when at least $80 \%$ of the occupants are comfortable within a space. The comfort temperature is a result of the interaction between the residents and the built environment they are occupying. The clothing level, type of activity and environmental variables such as air temperature, humidity, air velocity and radiation affect thermal sensation and satisfaction of occupants [21].

In environmental control context, first two questions of the interview were about thermal comfort. The users were asked to express how they feel about the indoor temperature of the mosque during winter and summer seasons. Graph 1 reflects the answer for summer, while Graph 2 reflects the answer for winter.

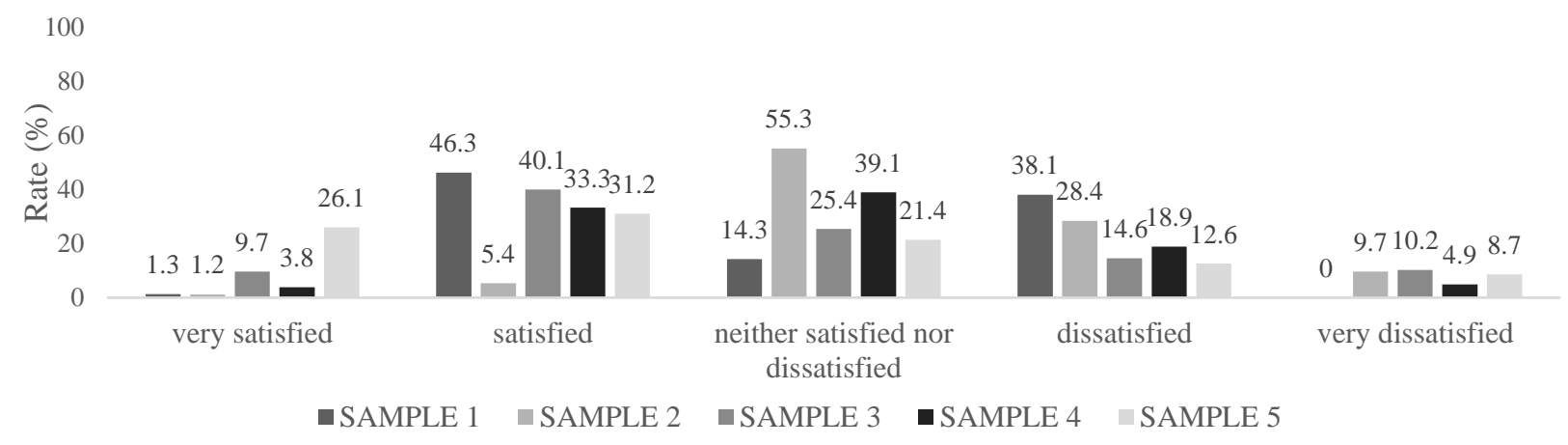

Graph 1: The user perception of thermal comfort in summer

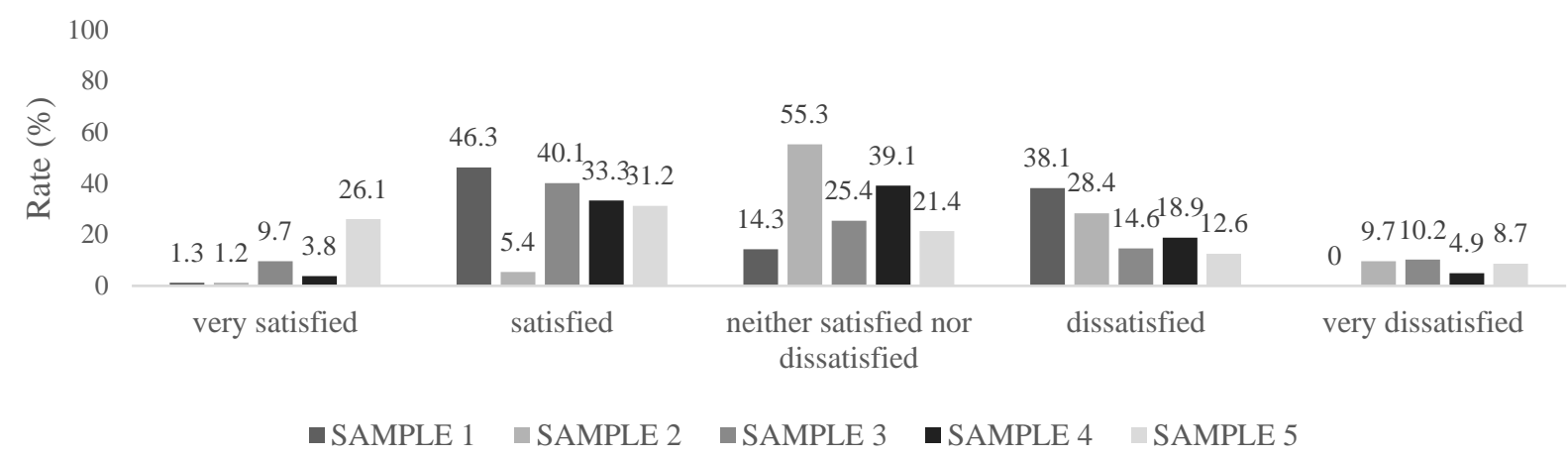

Graph 2: The user perception of thermal comfort in winter

Next questions object to cover acoustical comfort perception of users in terms of acoustical characteristics of houses volume, indoor and outdoor noise problem (Graph 3- Graph 4).

Indoor daylight and artificial illumination level along are discussed as the preconditions of visual comfort. Graph 5 reflects the satisfactory state of daylight use while Graph 6 reflects the user views on artificial illumination. 


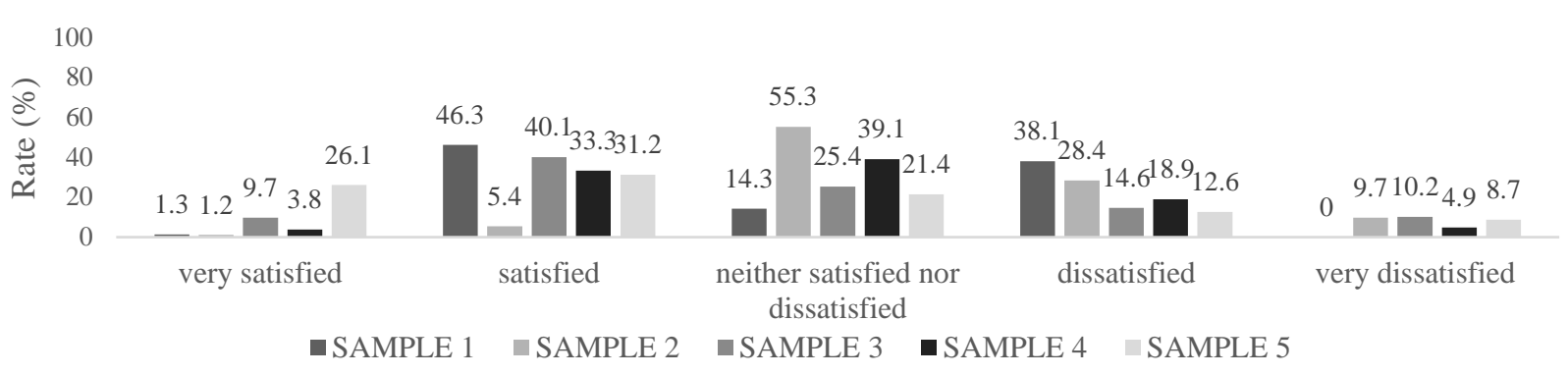

Graph 3: The user perception of indoor acoustical comfort and noise control

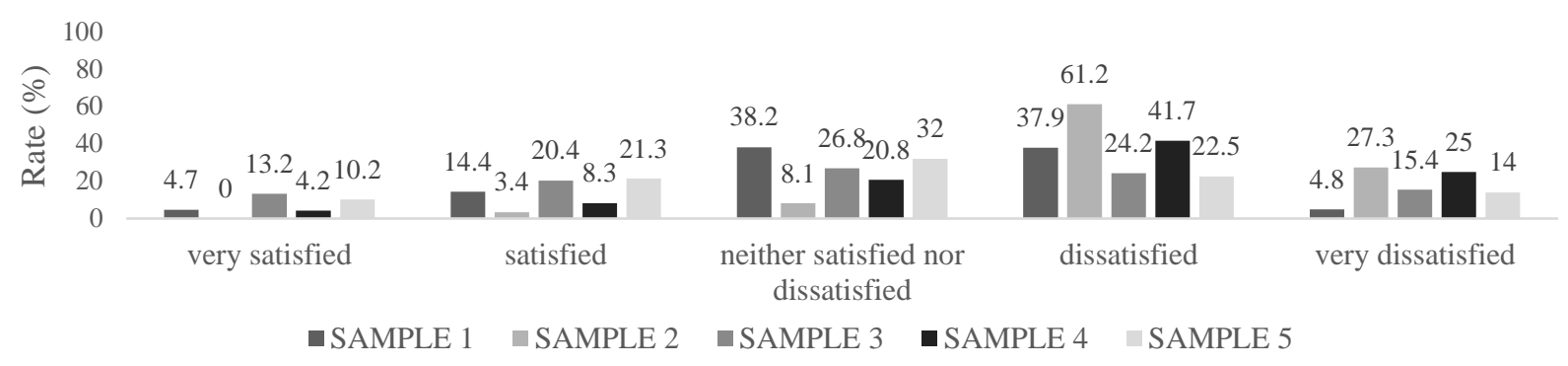

Graph 4: The user perception of outdoor acoustical comfort and noise control

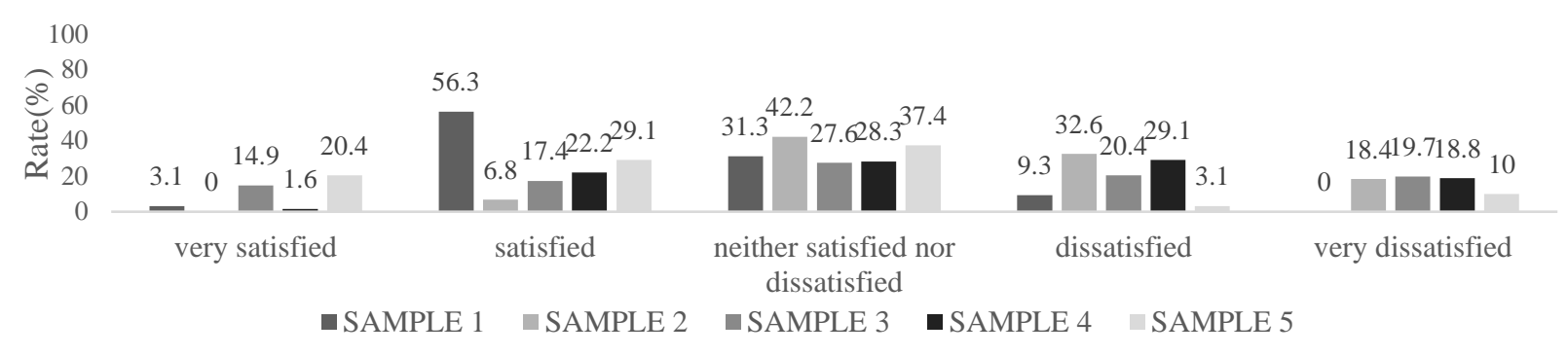

Graph 5: The user perception of indoor daylight level in houses

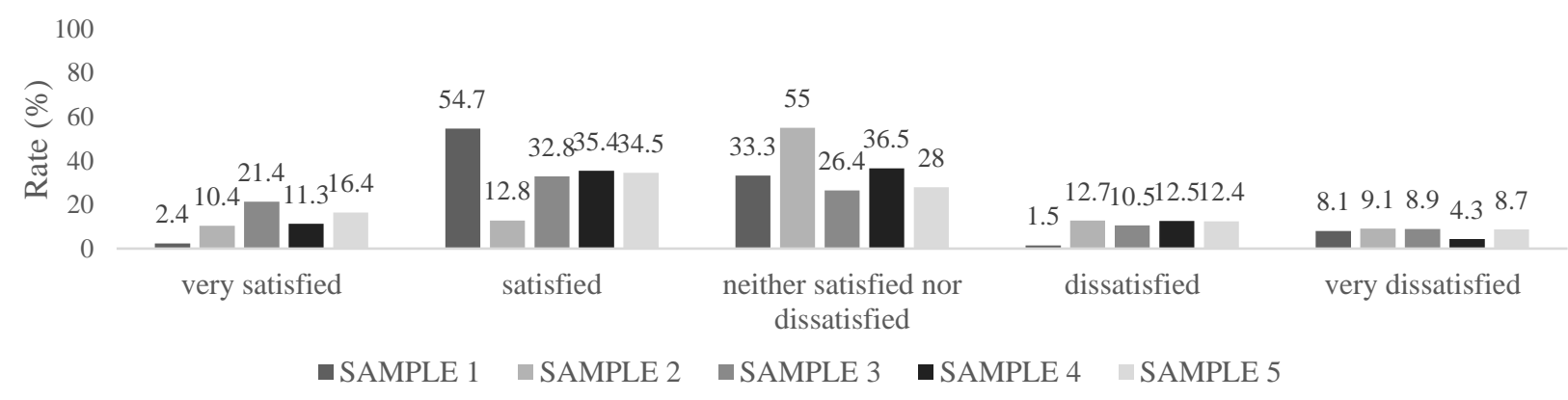

Graph 6: The user perception of indoor artificial illumination level in houses

The objective of this study is to discover users' views in with respect to achieving optimal comfort conditions in houses. The satisfaction level of respondents in the eight case studies were obtained for thermal environment, acoustic issues and lighting. Table 2 shows the general evaluation of user vies in all housing estates. 
Table 2: Satisfaction rate related to comfort conditions in the case housing estates

\begin{tabular}{|l|c|c|c|c|c|}
\hline & $\begin{array}{c}\text { Very } \\
\text { Satisfied } \\
(\boldsymbol{\%})\end{array}$ & $\begin{array}{c}\text { Satisfied } \\
(\boldsymbol{\%})\end{array}$ & $\begin{array}{c}\text { Neither Satisfied } \\
\text { nor Dissatisfied } \\
(\boldsymbol{\%})\end{array}$ & $\begin{array}{c}\text { Dissatisfied } \\
(\boldsymbol{\%})\end{array}$ & $\begin{array}{c}\text { Very } \\
\text { Dissatisfied } \\
(\%)\end{array}$ \\
\hline $\begin{array}{l}\text { Indoor air } \\
\text { temperature in } \\
\text { summer }\end{array}$ & 7 & 30 & 38 & 9 & 16 \\
\hline $\begin{array}{l}\text { Indoor air } \\
\text { temperature in } \\
\text { winter }\end{array}$ & 8 & 31 & 31 & 23 & 7 \\
\hline $\begin{array}{l}\text { Indoor noise } \\
\text { problem }\end{array}$ & 7 & 14 & 33 & 31 & 15 \\
\hline $\begin{array}{l}\text { Outdoor noise } \\
\text { problem }\end{array}$ & 6 & 14 & 25 & 38 & 17 \\
\hline Daylight & 8 & 26 & 33 & 19 & 14 \\
\hline Artificial light & 12 & 34 & 36 & 10 & 8 \\
\hline
\end{tabular}

The user evaluations are tabulated in Table 3 through the findings from the questionnaires that are analyzed using the Tables 1 and 2. Negative aspects are marked with bold characters.

Table 3: Satisfaction scores related to comfort conditions in the case housing estates

\begin{tabular}{|c|c|c|c|c|c|c|c|c|c|c|c|c|}
\hline \multirow{2}{*}{$\begin{array}{l}\text { User } \\
\text { Satisfaction }\end{array}$} & \multicolumn{2}{|c|}{ Sample 1} & \multicolumn{3}{|c|}{ Sample 2} & \multicolumn{2}{|c|}{ Sample 3} & \multicolumn{2}{|c|}{ Sample 4} & \multicolumn{2}{|c|}{ Sample 5} & \multirow{2}{*}{$\frac{\text { average }}{\mathrm{D}}$} \\
\hline & $\mathbf{S}$ & D & $\mathbf{S}$ & D & $\mathbf{S}$ & D & $\mathbf{S}$ & D & $\mathbf{S}$ & D & $\mathbf{S}$ & \\
\hline $\begin{array}{l}\text { Indoor air } \\
\text { temperature } \\
\text { in summer }\end{array}$ & 46,2 & & & $-49,7$ & & $\begin{array}{l}- \\
30,7\end{array}$ & 40,1 & & 44,2 & & 10,02 & \\
\hline $\begin{array}{l}\text { Indoor air } \\
\text { temperature } \\
\text { in winter }\end{array}$ & 10,8 & & & -40 & 24,5 & & 12,2 & & 53,4 & & 12,18 & \\
\hline $\begin{array}{l}\text { Indoor noise } \\
\text { problem }\end{array}$ & & $\begin{array}{l}- \\
32,3\end{array}$ & & $-50,4$ & & $\begin{array}{l}- \\
24,7\end{array}$ & & - & & $\begin{array}{l}- \\
7,4\end{array}$ & & $-32,66$ \\
\hline $\begin{array}{l}\text { Outdoor } \\
\text { noise } \\
\text { problem }\end{array}$ & & $\begin{array}{l}- \\
23,7\end{array}$ & & $\begin{array}{l}- \\
112,4\end{array}$ & & $-8,2$ & & -75 & & $\begin{array}{l}- \\
8,8\end{array}$ & & $-45,62$ \\
\hline Daylight & 53,2 & & & $-62,6$ & & $\begin{array}{l}- \\
12,6 \\
\end{array}$ & & - & 46,8 & & & $-3,3$ \\
\hline $\begin{array}{l}\text { Artificial } \\
\text { Light }\end{array}$ & 41,8 & & 2,7 & & 47,3 & & 36,9 & & 37,5 & & 33,24 & \\
\hline
\end{tabular}

S: Satisfied D: Dissatisfied

When considered in terms of climatic comfort; the evaluation of the results related to indoor air temperature in summers in Sample 2 and Sample 3 showed dissatisfaction. It is seen that these houses were mainly receiving sunlight from the the south and west directions. Since no precautions were taken to block sunlight, it was determined that dissatisfaction in these houses were inevitable. Dissatisfaction with indoor air temperature in winters was only observed in Sample 2. This result shows that in residences with a central heating system, no limitations are applied in winters and 
the heating programmes are based on user comfort. However, the houses selected for this study were built in 2008, which was before the Energy Performance Regulations of Turkey, therefore none of them were obligated to have insulation and therefore none of the houses were insulated. Because of the lack of insulation, it was seen that achieving comfortable climate conditions was only possible with maximum fuel consumption.

When auditory comfort conditions were evaluated, it was seen that all of the opinions obtained from all sites on indoor noise problem were negative. Because of the lack of insulation on inner walls sound transmission between rooms were excessive. Satisfaction levels were also negative due to outdoor noise problems based on similar reasons.

From the viewpoint of visual comfort conditions, it was observed that residents in Sample 2, 3 and 4 gave negative feedback on natural daylight. The opinions of the users based on the survey regarding the proximity of buildings to each other are shown in Table 4. Parallel to the results shown in Table 4, in Sample 2, 3 and 4 the proximity of blocks was found to be an important factor of the discomfort (Table 4). No indication of dissatisfaction with artificial light was observed.

Table 4: Discomfort, satisfaction rate and satisfaction score in blocks close to each other

\begin{tabular}{|l|c|c|c|c|c|r|r|}
\hline & $\begin{array}{c}\text { Very } \\
\text { Satisfied } \\
(\boldsymbol{\%})\end{array}$ & $\begin{array}{c}\text { Satisfied } \\
(\boldsymbol{\%})\end{array}$ & $\begin{array}{c}\text { Neither Satisfied } \\
\text { nor Dissatisfied } \\
(\boldsymbol{\%})\end{array}$ & $\begin{array}{c}\text { Dissatisfied } \\
(\boldsymbol{\%})\end{array}$ & \multicolumn{2}{|c|}{$\begin{array}{c}\text { Very } \\
\text { Dissatisfied } \\
(\boldsymbol{\%})\end{array}$} & \multicolumn{2}{|c|}{$\begin{array}{c}\text { Satisfaction } \\
\text { Scores }\end{array}$} \\
\hline SAMPLE1 & 4,2 & 61,9 & 9,3 & 24,6 & 0 & $+45,7$ & $\mathbf{- 1 0 1 , 2}$ \\
\hline SAMPLE 2 & 2,5 & 4,2 & 19 & 38,2 & 36,1 & & $\mathbf{- 7 , 3}$ \\
\hline SAMPLE 3 & 12,8 & 24,1 & 24,4 & 20,4 & 18,3 & & $\mathbf{- 9 5 , 8}$ \\
\hline SAMPLE 4 & 4,2 & 0 & 20,8 & 45,8 & 29,2 & & +31 \\
\hline SAMPLE 5 & 21,7 & 25 & 25,7 & 17,8 & 9,8 & \\
\hline
\end{tabular}

It is known that $80 \%$ of the users should report positive opinions to be able to say that there is satisfaction from comfort standards. When we look at the levels of satisfaction from this point of view, it is seen that only in Sample 1 and Sample 2, "indoor air temperature in summers" was satisfactory. In Table 3, even though satisfaction scores were expressed with positive numbers, no comfort level has reached the $80 \%$ level. $80 \%$ user dissatisfaction was observed on "Indoor noise problem" and "Daylight" in Sample 2 and "outdoor noise problem" in Sample 4.

Climate comfort satisfaction is related to air flow and temperature levels, which is determined by the position and direction of the building and placement of other buildings around [12,13,14]. Discomfort with climatic comfort makes it difficult for the individual to adapt to house and the environment, and discomforting thermal experiences have a strong impact on the perceptions and expectations of individuals [13]. In addition, the lack of climatic comfort is among the factors causing cardiovascular diseases, asthma and other chronic respiratory symptoms [3]. Perceptions, anticipations and adaptive behaviors are shaped accordingly when individuals meet with similar disturbing climatic conditions in the future [13,15]. Dissatisfaction with climatic comfort, especially in the summer months at the Ataevler houses that face south and west is parallel with the findings in this study and reduces the suitability for healthy living. As seen in different studies, climatic comfort is the most important condition for user satisfaction, which creates dissatisfaction for users living in these houses. 
Various standards have been set because thermal comfort has an impact on health [3]. In addition to these standards, World Health Organization indicates that energy efficiency is an important goal for the future for healthy housing and well-being [18]. Increase in $\mathrm{CO} 2$ emisssions create air pollution, increase fuel costs, and have other negative outcomes. In this framework in order to provide energy efficiency, it is necessary to increase consciousness on insulation, respect set standards, and use systems and devices for energy efficiency, while taking into consideration the costs in housing design. In the residences observed in the Ataevler district, which have central heating systems, there are no energy saving plans for winters and the buildings lack of insulation; this is contrary to energy efficiency which is shown among important steps for the future by the WHO. Climate comfort conditions at Ataevler are provided with maximum fuel consumption, which negatively affects the satisfaction of the users both in terms of air quality and economically. Studies indicate that use of fans and windows for controlling of indoor conditions are the preferred methods by users and the availability of these have a positive effect on the satisfaction from climatic comfort $[3,13,14]$. It is necessary to consider views of residential users for creating policies to produce healthy housing [18]. The discomfort from climatic comfort in summer months in the houses in the Ataevler district indicate that there are problems with layout of sites, residential equipment, size of the facade gaps, height of apartments affecting airflow. Because energy efficiency is also a problem in winter months, it will be beneficial to apply insulation, select appropriate windows and install various energy efficiency systems. Designers should pay more attention to incorporating housing elements and systems that the user can control to improve both energy efficiency and the user's climate comfort satisfaction.

Lack of insulation in residences negatively affects the level of satisfaction with the auditory comfort because of problems from outdoor noise and noise passing between indoor spaces. In the literature, it is observed that the satisfaction from auditory comfort conditions decreases in the dwellings located in the city center [8]. In a separate study in Finland, traffic noise disturbance has been a factor reducing satisfaction in apartment blocks and urban dwellings [11]. The dissatisfaction with the auditory comfort conditions in Ataevler is inline with the findings in the literature since the housing estates are in the center of the city and in an area with high traffic. Users can feel uncomfortable when audible comfort is not achieved [4]. The excessive noise commonly seen in poorly insulated housing units is regarded as one of the problems causing sleep deprivation, which causes psychological stress and negative effects on sympathetic nervous system. Negative psychological responses to noise-related environmental stressors cause health problems and have negative effects on the organism [3]. Lack of insulation, urban noise and high traffic at the Ataevler sites reduces the level of auditory comfort. The decrease in auditory comfort is accompanied by an adverse effect on user satisfaction of those dwellings.

Similar to climatic comfort, satisfaction from daylight is related to size of window openings, density of the residential area, height of buildings, distance between buildings, and placement of different building blocks $[13,16,17]$. As seen in Table 4, the difficulty of taking natural daylight in houses in blocks that the users find very close to each other is an important factor that reduces visual comfort. $\mathrm{Ng}$. (2003) emphasizes the importance of the distance between buildings in order to benefit from the daylight, Xue et al. (2014) indicates that artificial lighting is needed if daylight is limited and this reduces user satisfaction from dwellings. Different brightness levels created by natural light allow users to select the best environment to their requirements. Artificial lighting does not enrich the interior but only provides light. Houses with insufficient natural light create 
dark places and increase necessity for artificial lighting during daytime hours, which negatively affects user satisfaction from the interior of the dwelling and at the same time is both economically disadvantageous and is not energy efficient.

\section{Conclusions and Recommendations}

In this study, it was aimed to reveal the expectations of the users about the climatic, acoustic and visual comfort conditions of a residence and their satisfaction with these expectations. The results obtained from the study show that "indoor noise problems", "outdoor noise problems" and inadequacy of daylight in houses are the leading factors of discomfort of middle income users. The users can be physically and psychologically healthy and productive in the built environments only if optimal comfort conditions are provided. The results show that, achieving optimal visual, acoustical, and climatic comfort conditions is essential to create a positive impact on users' performance in houses. Furtherly, this knowledge can contribute towards the improvement of future house designs addressing user comfort parameters for indoors.

To avoid such problems, care must be taken in the planning and design phases of residences to ensure that sufficient daylight can be achieved, that distance between building blocks create enough space for daylight, that heat and sound insulation are planned in accordance with standards, and user awareness is increased for building selection that could provide optimum indoor comfort conditions. When the results obtained from the study are evaluated, as the hypothesis also indicates, it is observed that the priority in housing design for middle income groups is to provide houses rather than focusing on interior comfort conditions. Therefore, user satisfaction from comfort conditions is inevitably adversely affected. To make the residences healthier and better in terms of their thermal, visual and auditory comfort conditions and to increase the comfort and their satisfaction of the users and to facilitate their adaptation to their houses, dwelling producers should give utmost importance to design and application of facade gaps, density, height and layout of apartments, as well as providing good insulation.

In the next stages of the study, it is planned to evaluate other factors such as recreative spaces, layout, number of rooms and safety perception, which have an impact on user satisfaction. To increase comfort conditions and user satisfaction, it is necessary for politicians, producers and users to put emphasis on high quality, healthy and energy efficient residence production and purchase and to optimize the balance between housing quality and economic valuation.

\section{References}

[1] WHO, Air quality guidelines for Europe. WHO Regional Publications, European Series, World Health Organization, Regional Office for Europe, 2000.

[2] Braubanch, M. Key challenges of housing and health from WHO perspective, International Journal of Public Health, 2011, 56: 579-580.

[3] Krieger, J., Higgins, D. L. Housing and Health: Time Again for Public Health Action, American Journal of Public Health, 2002, Vol 92, No.5: 758-768.

[4] Huang, L., Zhu, Y., Ouyang, Q., Cao, B. A study on the effects of thermal, luminous, and acoustic environments on indoor environmental comfort in offices, Building and Environment Vol. 49, 2012: 304-309. 
[5] Ormandy, O., Ezratty, V. Health and thermal comfort: From WHO gouidance to housing strategies. Energy Policy Vol. 49, 2012: 116-121.

[6] Hasselaar, E. Health performance of housing: Indicators and tools, 2006, IOS Press under the imprint Delft University Press

[7] de Silva, S. M., de Almeida, M. G. Thermal and acoustic comfort in buildings, Internoise 15-16 June 2010, Portugal.

[8] Türkoğlu, H. D. Residents' satisfaction of housing environments: the case of Istanbul, Turkey, Landscape and Urban Planning Vol. 39, 1997: 55-67.

[9] Jiboye, A.D. The correlates of public housing satisfaction in Lagos, Nigeria, Journal of Geography and Regional Planning Vol. 3(2), 2010: 017-028.

[10] Ibem, E. O., Aduwo, E. B. Assessment of residential satisfaction in public housing in Ogun State, Nigeria, Habitat International Vol. 40, 2013: 163-175.

[11] Pekkonen , M., Haverinen-Shaughnessy, U. Housing satisfaction in Finland with regard to area, dwelling type and tenure status, Central European Journal of Public Health, Vol. 23 (4), 2015: 314320.

[12] Frontczak, M., Andersen, R.V., Wargocki, P. Questionnaire survey on factors influencing comfort with indoor environmental quality in Danish housing, Building and Environment, Vol. 50, 2012, 56-64.

[13] Wong, N. H., Feriadi, H., Lim, P. Y., Tham, K. W., Sekhar, C., Cheong, K. W. Thermal comfort evaluation of naturally ventilated public housing in Singapore, Building and Environment Vol. 37, 2002: $1267-1277$.

[14] Soebarto, V., Bennetts, H. Thermal comfort and occupant responses during summer in a low to middle income housing development in South Australia. Building and Environment, Vol. 75, 2014, 19-29.

[15] Feriadi, H., Wong, N. H. Thermal comfort for naturally ventilated houses in Indonesia, Energy and Buildings, Vol. 36, 2004: 614-626.

[16] Xue, P., Mak, C. M., Cheung, H.D. The effects of daylighting and human behavior on luminous comfort in residential buildings: A questionnaire survey, Building and Environment, Vol. 81, 2014, 51-59.

[17] $\mathrm{Ng}$, E. Studies on daylight design and regulation of high density residential housing in Hong Kong, Lighting Research\& Technology, Vol. 35, 2, 2003: 127-139.

[18] WHO (World Health Organization), Housing, energy and thermal comfort: A review of 10 countries within the WHO European Region, 2007

[19] SPSS 13.0 for Windows Program

[20] https://www.google.com.tr/intl/tr/earth/

[21] ANSI/ASHRAE Standard 55-2010: Thermal environmental conditions for human occupancy, ASHRAE, Atlanta, GA, USA. (Online) Available:

http://arco-hvac.ir/wp-content/uploads/2015/11/ASHRAE-55-2010.pdf (June 22, 2018).

*Corresponding author.

E-mail address: miraygur@ yahoo.com 